\title{
Perilaku Mahasiswa Pariwisata Menggunakan Media Sosial Untuk Mempromosikan Destinasi Wisata
}

\author{
Any Noor ${ }^{1}$, Marceilla Suryana ${ }^{2}$, Sholihati Amalia ${ }^{3}$ \\ ${ }^{1}$ Politeknik Negeri Bandung, anynoor@polban.ac.id \\ ${ }^{2}$ Politeknik Negeri Bandung, suryanamarceilla@gmail.com \\ ${ }^{3}$ Politeknik Negeri Bandung, liasuwardi@gmail.com
}

\begin{abstract}
ABSTRAK
Tingginya penggunaan media sosial dalam kegiatan wisata berdampak pada kemampuan mahasiswa pariwisata mengadaptasi perkembangan teknologi, khususnya media sosial. Penelitian ini difokuskan pada perilaku mahasiswa pariwisata menggunakan media sosial untuk mempromosikan destinasi wisata Indonesia. Metode penelitian kualitatif digunakan untuk mendapatkan pemahaman mengenai perilaku mahasiswa pariwisata. In depth interview dilakukan pada 26 mahasiswa pariwisata di wilayah Bandung, Jakarta dan sekitarnya. Teknik analisis konten dilakukan untuk mendapatkan kesimpulan mendalam yang mempengaruhi mahasiswa pariwisata menggunakan media sosial dalam konteks pariwisata. Hasil penelitian menunjukkan bahwa mahasiswa pariwisata memiliki kemampuan menggunakan media sosial untuk membuat blog dan vlog dengan aplikasi yang tersedia. Mahasiswa pariwisata memiliki keiinginan untuk mempromosikan destinasi wisata melalui akun media sosial yang dimilikinya. Temuan lainnya menunjukkan bahwa mahasiswa memiliki keiinginan dan sudah mulai berbisnis menggunakan media sosial dalam bidang yang berhubungan dengan pariwisata, seperti membuat paket wisata dan menjualnya.
\end{abstract}

Kata Kunci: Media Sosial, Mahasiswa Pariwisata, Promosi Destinasi Wisata

\begin{abstract}
The high use of social media in tourism activities has an impact on the ability of tourism university student to adapt technological developments, especially social media. This study focuses on the tourism university student behavior in using social media to promote Indonesia tourist destinations. Qualitative research methods used to gain an understanding of tourism student behavior. In depth interview conducted to 26 tourism university students in the areas of Bandung and Jakarta. Content analysist conducted in developing conclusion that affect students using social media for tourism context. The results show that tourism university students have the ability to use social media in creating blogs and vlog using available applications. Tourism students have willingness to promote tourist destinations though their social media accounts. Other findings indicate that student tend to do business in tourism related areas such as making and selling tour packages.
\end{abstract}

Keywords: Social Media, Tourism University Students, Tourist Destination Promotion

Diterima: 20 Agustus 2018, Direvisi: 15 Mei 2019, Diterbitkan: 15 Agustus 2019

\section{PENDAHULUAN}

Saat ini, arus informasi di internet berkembang dengan sangat pesat. Awalnya, internet berperan sebagai pusat informasi, tetapi saat ini internet sudah dapat berinteraksi dengan konsumen. Media sosial berkembang dengan sangat fenomenal didunia karena memungkinkan pemilik akun berinteraksi dengan beragam kalangan. Sepanjang tahun 2017, Facebook merupakan satu-satunya media sosial dengan jumlah pengguna aktif mencapai 1,74 miliar atau mencapai $22 \%$ dari total populasi dunia.
Perkembangan pengguna internet dan media sosial adalah $10 \%$ dari tahun 2015-2016. Instagram adalah media sosial banyak digunakan oleh remaja berusia 18-29 tahun. Pengguna SnapChat sudah mencapai 150 juta platform perharinya melalui konten baik foto dan video pada layanan epheremal messaging ini, hal ini telah mengalami kenaikan yang cukup tinggi dibandingkan pada bulan Desember 2015 yang hanya sejumlah 110 juta pengguna (Mukaromah, Kusyanti, \& Perdanakusuma, 2018) 
Sejak internet pertama kali dikenalkan dalam bisnis sebagai salah satu saluran komunikasi pemasaran yang penting, volume transaksi tertinggi secara online dihasilkan oleh bisnis pariwisata (Akehurst, 2009; Werthner \& Ricci, 2004). Dalam perkembangannya, media sosial telah menjadi saluran pemasaran yang efektif dan penting untuk pemasaran jasa pariwisata (Zeng \& Gerritsen, 2014). Dengan demikian, perkembangan media sosial memberikan peluang dan tantangan bagi usaha pariwisata. Tidak mengherankan bahwa kuatnya hubungan antara teknologi informasi dan industri parwisata telah menjadikan media sosial sebagai saluran yang penting dan populer dengan isu-isu perjalanan wisata. Lebih dari $80 \%$ konsumen online melakukan keputusan pembelian yang berhubungan dengan perjalanan wisata. Penggunaan sosial media tidak terbatas pada tahap pra wisata saja, tetapi konsumen menggunakannya pada setiap tahap perjalanan, seperti rencana perjalanan, destinasi tujuan, ulasan hotel, pemandu wisata dan saran untuk restoran (Fotis, Buchalis, \& Rossides, 2012; Pantano \& Di Pietro, 2013).

Media sosial merupakan trend yang dominan mempengaruhi perilaku konsumen di berbagai aspek, termasuk pariwisata. Mayoritas pengguna media sosial adalah orang yang dikelompokan sebagai generasi muda, yang karakteristiknya dapat diwakili oleh generasi $\mathrm{Y}$ atau generasi milenial, yaitu generasi pertama yang menghabiskan waktunya di lingkungan digital dan teknologi informasi (Bennet, Maton, \& Kervin, 2008). Dalam studi ini, generasi Y diwakili oleh mahasiswa pariwisata, sehingga penggunaan media sosial dalam konteks pariwisata menjadi fokus utama yang diteliti.

Perilaku mahasiswa pariwisata menggunakan media sosial masih belum banyak mendapat perhatian, Hal ini terlihat dari masih rendahnya data empiris mengenai penggunaan media sosial dalam bidang pariwisata. Faktanya, media sosial banyak mempengaruhi perkembangan pariwisata, misalnya untuk promosi destinasi wisata dan mempengaruhi orang untuk melakukan kegiatan wisata. Dengan demikian, penelitian ini bermaksud untuk memahami perilaku mahasiswa pariwisata menggunakan media sosial untuk memasarkan destinasi wisata. Hal tersebut akan diketahui melalui tujuan penelitian ini dengan menganalisa untuk pemahaman mahasiswa pariwisata terhadap konsep media sosial, analisa perilaku mahasiswa pariwisata dalam menggunakan media sosal untuk konten destinasi wisata, serta mengidentifikasi potensi media sosial sebagai sarana promosi destinasi wisata oleh mahasiswa pariwisata.

\section{KAJIAN PUSTAKA \\ Media Sosial}

Dengan perkembangan internet yang cepat diawal tahun 2004, konsumen tidak harus bergantung lagi pada sumber informasi yang diberikan oleh perusahaan, tetapi konsumen akan dengan mudah mendapatkan informasi dari konsumen lainnya. Beragam aplikasi muncul untuk mendapatkan informasi yang dikenal dengan media sosial. Aplikasi media sosial tumbuh dan berkembang sangat pesat dengan beragam jenis yang memberikan banyak kesempatan bagi penggunanya mengekspresikan diri dan bertukar konten (Fotis, et al., 2012). Media sosial adalah internet berbasis aplikasi pengguna kelompok yang memungkinkan terjadinya pertukaran informasi dari sesama pengguna (Kaplan \& Haenlein, 2010). Media sosial digunakan untuk kebutuhan komersil, karena mampu memberikan beragam informasi secara online yang dibuat, disebarkan dan digunakan oleh konsumen. Seluruh informasi online tersebut memberikan pengetahuan dan informasi kepada para pengguna mengenai produk, merek, pelayanan, kebutuhan personal dan isu-isu terbaru (Lange-Faria \& Elliot, 2012; Mangold \& Faulds, 2009; Zeng \& Gretzel, 2010).

Media sosial adalah sebuah media online dimana para penggunanya melalui aplikasi berbasis internet dapat berbagi, berpartisipasi dan menciptakan konten berupa blog, wiki, forum, jejaring sosial dan ruang dunia virtual yang didukung oleh teknologi multimedia. Media sosial yang paling banyak digunakan dan tumbuh pesat berupa jejaring sosial, blog dan wiki. Pengguna media sosial dapat dengan bebas mengedit, mengurangi, menambahkan, menyebarkan dan memodifikasi tulisan, gambar, video dan berbagai bentuk konten lainnya dalam sosial media (Kemendag, 2015).

Heinlein dalam Kemendag (2014) menjelaskan klasifikasi jenis media sosial berdasarkan ciri penggunaannya dibagi menjadi enam jenis:

1. Proyek kolaborasi website; user diizinkan untuk mengubah, menambah, dan membuang konten yang dimuat di website, seperti Wikipedia.

2. Blog atau microblog; user mendapat kebebasan dalam mengungkapkan suatu hal 
di blog, seperti perasaan, pengalaman, pernyataan dan kritik terhadap suatu hal, seperti Twitter.

3. Konten atau isi, pengguna di dapat saling membagikan konten-konten multimedia, seperti e-book, video, foto, gambar. Jenis yang banyak digunakan adalah Youtube.

4. Situs jejaring sosial, user memiliki izin untuk terkoneksi dengan cara membuat informasi bersifat pribadi, kelompok atau sosial untuk dapat terhubung dan diakses oleh orang lain, misalnya Facebook

5. Virtual game world, melalui aplikasi 3D pengguna dapat muncul dalam wujud avatar sesuai keinginan dan berinteraksi dengan orang lain dalam wujud avatar lainnya seperti di dunia nyata seperti online game.

6. Virtual social world, merupakan aplikasi dunia virtual yang memberikan kesempatan kepada penggunanya berada dan hidup di dunia virtual untuk berinteraksi dengan pengguna lain.

Berdasarkan klasifikasi sosial media yang sering digunakan saat ini, maka media sosial memiliki ciri-ciri sebagai berikut (Heinlein dalam Kemendag, 2015):

1. Konten yang dapat dibagikan kepada banyak orang dan tidak terbatas.

2. Isi pesan muncul tanpa melalui suatu gatekeeper dan tidak ada penghambat.

3. Isi disampaikan secara online dan langsung

4. Konten dapat diterma secara online dalam waktu yang cepat atau ditunda tergantung pada waktu interaksi yang ditentukan oleh penggua

5. Sosial media menjadikan pengguna sebagai creator dan aktor yang memungkinkan dirinya beraktualisasi diri

6. Dalam konten sosial media terdapat jumlah aspek fungsional, seperti identitas, percakapan (interaksi), berbagi (sharring), kehadiran (eksis), status (reputasi), dan kelompok (group).

Pariwisata adalah salah satu topik yang menarik bagi banyak kalangan pengguna internet, terlihat dari ramainya pariwisata diperbincangkan dan para pengguna membuat banyak akun, seperti blog, twitter, instagram, path dan facebook. Akun tersebut dapat diakses dengan mudah melalui personal komputer ataupun telepon pintar dan tablet yang keseluruhannya telah menjadi bagian sehari-hari pengguna (Hamzah, 2013).

\section{Perilaku konsumen pengguna media sosial}

Pengguna sosial media yang aktif diidentifikasi sebagai kelompok yang memiliki kemudahan mengakses dan menggunakan teknologi. Mahasiswa adalah kelompok yang rentan terhadap ketergantungan pada internet dibanding kelompok lainnya (Kandell, 1998). Penggunaan internet oleh mahasiswa lebih penting dibandingkan dengan kelompok lain pada umumnya, karena aktivitas online dapat memperluas dan memperkuat jaringan sosial yang dimilikinya (Smahel, Brown, \& Blinka, 2012). Berdasarkan karakteristik kelompok mahasiswa, maka generasi mahasiswa saat ini dikelompokkan dalam generasi Y.

Generasi Y (Gen Y) atau Generasi Millenial adalah generasi pertama yang menghabiskan waktunya dalam lingkungan digital dan teknologi informasi yang mempengaruhi kehidupan dan pekerjaannya (Bennett, et al., 2008; Wesner \& Miller, 2008). Gen Y berkontribusi aktif dalam menyebarkan konten yang dapat digunakan oleh konsumen untuk bekerja dan bermain melalui media sosial. Gen $\mathrm{Y}$ adalah orang yang lahir antara tahun 1981- 1999 (Brosdahl \& Carpenter, 2011). Mayoritas pengguna media sosial berusia antara 18-34 tahun. Media sosial digunakan untuk berinteraksi dan berhubungan dengan teman dan keluarga, kelompok ini lebih menyukai memberikan penilaian dan opini melalui media sosial dan merasa penting ketika mendapatkan umpan balik tentang produk dan merek yang mereka gunakan (eMarketer, 2011). Gen Y adalah kelompok orang yang menggunakan media sosial untuk berinteraksi dengan orang lain (Palfrey \& Gasser, 2008).

Kelompok Gen Y adalah generasi yang dapat dipercaya, memiliki toleransi yang tinggi dan lebih baik dalam melakukan perjalanan daripada orang tua mereka. Gen Y memiliki sikap sosial dan bertanggungawab (Furlow, 2011). Gen Y memiliki karakteristik individualis, berpendidikan baik, mudah beradaptasi dengan teknologi dan dewasa (Syrett \& Lammiman, 2003). Berbeda dengan generasi sebelumnya, kelompok ini ditandai dengan sifat materialistis dengan budaya yang diciptakan karena inovasi teknologi (Hanzaee \& Aghasibeig, 2010).

Sejak aplikasi media sosial berkembang di tahun 2004 (Fotis, et al., 2012), banyak digunakan usergenerated service, seperti blogs, jaringan media sosial, online review atau rating sites, permainan virtual, video sharing dan komunitas online lainnya dimana konsumen dapat digunakan untuk memproduksi, mendesain, mempublikasikan atau melakukan perubahan konten (Krisnamurthy \& 
Dou, 2008). Konten aplikasi media sosial inilah yang banyak digunakan oleh Gen Y.

\section{Media sosial dan pariwisata}

Peran media sosial dalam pariwisata meningkat dengan sangat pesat dan mulai menjadi topik yang berkembang untuk diteliti (Zeng, 2013). Media sosial memainkan peran yang sangat penting dalam beragam aspek pariwisata, terutama dalam pencarian informasi dan mempengaruhi keputusan wisatawan berperilaku (Fotis, et al., 2012), media sosial sebagai bagian penting dalam promosi pariwisata fokus pada interaksi antara konsumen melalui saluran media sosial dalam bentuk memberikan pengalaman berwisata (Bradbury, 2011).

Industri pariwisata merupakan sektor yang banyak mengadopsi teknologi informasi. Internet merupakan aplikasi kunci dalam bisnis pariwisata. Konsumen dapat dengan mudah berinteraksi dengan penyedia jasa pariwisata melalui perubahan kebutuhan yang cepat di industri ini. Noti (2013) menjelaskan bahwa penyedia jasa pariwisata dapat lebih efektif memenuhi kebutuhan konsumen. Penyedia jasa pariwisata sudah terbiasa menggunakan internet untuk berkomunikasi, mendistribusikan dan memasarkan produk kepada konsumen potensial di seluruh dunia dengan waktu dan cara yang efisien.

Aplikasi teknologi melalui media sosial menjadi faktor utama karena konsumen mampu mengevaluasi pengalaman melalui produk dan jasanya. Media sosial telah banyak dimanfaatkan untuk distribusi produk pariwisata. Perkembangan pelayanan online sudah menjadi hal yang biasa, dan konsumen saat ini memiliki kontrol untuk membuat keputusan untuk kegiatan perjalanan wisata (Noti, 2013).

Media sosial memiliki peran yang sangat penting sebagai sumber informasi untuk wisatawan. Hal ini terlihat dari peningkatan jumlah mesin pencari dalam konteks pariwisata. Media sosial menjadi bagian penting dalam pemasaran online sebagai mesin penyedia jasa parwisata. Suksesnya perusahaan penyedia jasa pariwisata karena mampu mengidentifikasi kebutuhan konsumen, dan berinteraksi dengan klien yang menggunakan media sosial (Noti, 2013).

\section{METODE PENELITIAN \\ Desain Penelitian}

Penelitian ini menggunakan model kualitatif untuk mendapatkan persepsi yang utuh mengenai perilaku Gen Y yang diwakiliki oleh mahasiswa pariwisata menggunakan media sosial. Informan dalam penelitian ini adalah 26 mahasiswa pariwisata di Bandung dan Jakarta yang berasal dari universitas, sekolah tinggi dan politeknik, baik negeri maupun swasta. Teknik pengumpulan data dilakukan dengan cara semi structured interview. Data atau informasi dikumpulkan berasal dari opini, perilaku, fakta dan pengetahuan mahasiswa pariwisata menggunakan media sosial. Teknik pengumpulan data ini menghasilkan informasi yang akurat dan mendalam serta memenuhi kebutuhan informasi dalam penelitian ini. Validasi data dilakukan dengan Teknik triangulasi sumber, dan triangulasi waktu (Sugiyono, 2006). Triangulasi sumber yaitu data didapat dari mahasiswa pariwisata dari Bandung dan Jakarta. Triangulasi waktu yaitu data didapat selama bulan Juli 2017.

Data yang terkumpul berupa transkrip dengan panjang sekitar 2000 kata yang selanjutnya diolah untuk dilakukan pengkodean. Kode difokuskan pada teori yang digunakan dalam penelitian ini selanjutnya dikembangkan untuk dilakukan analisis dari data yang didapat (Charmaz, 2006). Analisis interaktif digunakan dengan menerapkan reduksi data, penyajian data dan penarikan kesimpulan (Miles \& Huberman, 1992).

\section{HASIL DAN PEMBAHASAN \\ Analisis Data}

Data yang disampaikan didasarkan pada teori yang digunakan dan hasil nya dikelompokkan dalam 3 kategori utama sesuai hasil pengkodean, yaitu:

1. Perilaku online

2. Kemampuan menggunakan media sosial

3. Potensi penggunaan media sosial

\section{Kategori 1: Perilaku online}

Perilaku online menunjukkan bahwa 26 orang informan merupakan mahasiswa aktif berusia 1823 tahun dan seluruhnya menggunakan media sosial. Jumlah akun media sosial yang dimiliki mahasiswa antara 3 sampai 7 akun. Dengan jumlah akun tersebut, rata-rata mahasiswa menghabiskan waktu antara 4-7 jam sehari menggunakan media sosial. Akun media sosial yang dimiliki oleh semua informan adalah Instagram dan Facebook. Akun lainnya yang digunakan, tetapi tidak oleh seluruh informan adalah Path, Twitter, Pinterest, Line dan WhatsApp. 
Perilaku mahasiswa pariwisata menggunakan media sosial sesuai dengan tujuan dalam penelitian ini, yaitu difokuskan pada isu pariwisata. Sehingga konten wisata di media sosial menjadi pertanyaan penting. Hasil penelitian menunjukkan bahwa isu pariwisata menarik minat mahasiswa pariwisata untuk mendapatkan beragam informasi mengenai segala hal yang berhubungan dengan pariwisata, terutama destinasi wisata. Konten pariwisata di media sosial yang dikunjungi mahasiswa adalah destinasi, isu-isu pariwisata terkini, baik mengenai destinasi, atraksi, harga, akomomasi, destinasi yang baru, serta berita terkini mengenai pariwisata.

Aktivitas mahasiswa pariwisata di media sosial sangat beragam, hasil penelitian menunjukkan aktivitas yang paling banyak dilakukan adalah:

1. Mencari tempat wisata atau destinasi baru di Indonesia dan dunia

2. Mencari informasi baru dan konsep berwisata yang islami

3. Mencari informasi mengenai pariwisata untuk mendapatkan jaringan dengan website lain, seperti CNN

4. Mencari tahu mengenai akses, harga tiket, program promosi, dan akomodasi di destinasi.

5. Mencari informasi mengenai atraksi wisata

6. Mencari tren pariwisata baru yang belum banyak diketahui

Hal lain yang muncul, tidak berdasarkan panduan wawancara, tetapi respon mahasiswa menjelaskan perasaannya ketika mahasiswa menuliskan informasi, pengalaman berwisata memasang foto atau video di akun media sosial adalah mahasiswa menjadi seseorang yang bahagia dan penting. Kondisi ini berlanjut, ketika mendapatkan penilaian positif dari orang lain tentang apa yang mereka lakukan dalam perjalanan wisata. Beberapa ungkapa perasaan bahagia dan penting yang disampaikan mahasiswa:

1. 'saya senang kalau ada yang kasi 'like' atau komen bagus..."

2. “... banyak yang memberikan komentar positif dan mereka suka dengan apa yang saya posting"

3. "senang sekali kalau ada yang kasi komentar..."

Kategori 2: kemampuan menggunakan media sosial
Kemampuan mahasiswa pariwisata menggunakan media sosial merupakan fokus selanjutnya dalam penelitian ini. Hasil penelitian menunjukkan bahwa mahasiswa pariwisata memiliki kemampuan untuk menciptakan sesuatu melalui media sosial. Kemampuan utama yang dimiliki mahasiswa pariwisata adalah membuat blog dan vlog. Meskipun demikian, tidak semua mahasiswa pariwisata mampu menghasilkan sesuatu di media sosial. Hanya 3 orang dari total 26 mahasiswa yang tidak dapat menggunakan media sosial untuk membuat blog dan vlog. Hal ini ditunjukkan dari informasi yang disampaikan ketiga orang tersebut:

1. "Tidak begitu bisa menciptakan sesuatu di media sosial, terutama tidak bisa menyusun kalimat yang baik dan benar"

2. "Saya hanya bisa membuat blog saja dan saya tidak memiliki kemampuan menggunakan media sosial untuk membuat hal lainnya".

3. “.. saya rasa untuk saat ini saya belum mampu.."

Meskipun demikian, jumlah informan lainnya memiliki kemampuan untuk menciptakan sesuatu melalui media sosial, seperti yang disampaikan:

1. "saya mampu membuat blog, poster dan video"

2. "saya mampu membuat postingan di blog maupun media sosial lainnya"

3. "saya dapat membuat blog, vlog"

4. "dapat membuat akun wisata"

5. “... dulu pernah membuat blog ketika tugas sekolah yang menceritakan pengalaman berwisata disebuah gunung"

6. "ya... saya mampu menarik pembaca untuk membaca blog saya"

7. ".. saya dapat membuat youtube channel atau membuat postingan di Instagram atau FB"

8. "saya dapat memposting hasil foto terkait destinasi atau kuliner tertentu"

9. Ya.. saya membuat beberapa akun di beberapa media sosial"

Informasi diatas menunjukkan bahwa kemampuan mahasiswa pariwisata dapat membuat beragam konten pariwisata melalui media sosial. Selain itu, kemampuan memodifikasi informasi menggunakan media sosial juga ditunjukkan oleh mahasiswa pariwisata. Rangkuman informasi yang disampaikan mahasiswa mengenai kemampuan memodifikasi konten pariwisata yang dapat dilakukan adalah: 
1. Melakukan editing di blog

2. Melakukan editing foto dan video melalui aplikasi

3. Membuat redaksi, menganalisis hal yang perlu dipahami

4. Melakukan editing dan menyebarkan informasi mengenai destinasi wisata

5. Mengabadikan dengan foto dan video, menjadi sesuatu yang menarik dan posting di media sosial.

6. Melakukan editing berbasis aplikasi mobile, maupun web design.

7. Memberikan caption menarik pada informasi di media sosial untuk lebih menarik wisatawan berkunjung ke destinasi.

\section{Kategori 3: Potensi penggunaan media sosial}

Media sosial memiliki potensi yang digunakan oleh mahasiswa pariwisata untuk beragam kegiatan, terutama untuk mencari informasi yang berhubungan dengan kegiatan wisata. Media sosial digunakan pada dua tahap penting dalam kegiatan wisata, yaitu pada pre-tour dan post tour. Pada tahap pre-tour, media sosial digunakan oleh mahasiswa pariwisaa untuk mencari informasi mengenai:

1. Harga di destinasi, termasuk tarif masuk destinasi, biaya makan, biaya akomodasi, dan biaya untuk menikmati atraksi di destinasi.

2. Ulasan atau review pengunjung di destinasi untuk mengetahui tingkat kepuasan atau layanan di destinasi

3. Keindahan dan kebersihan destinasi

4. Hal yang boleh dan tidak boleh dilakukan di destinasi

5. Akses menuju destinasi, akomodasi yang khas, cinderamata dan oleh-oleh dari destinasi

6. Keunikan yang dimiliki destinasi, termasuk kebudayaan setempat dan hal menarik apa yang ada di destinasi

7. Tempat yang wajib dikunjungi di destinasi dan kuliner khas yang wajib dicoba.

Pada tahap post tour, media sosial digunakan mahasiswa pariwisata untuk memberikan informasi dan menuliskan pengalaman berwisata. Hampir seluruh mahasiswa pariwisata melakukan hal yang sama di media sosial setelah berwisata, terdiri dari:

1. Menuliskan pengalaman berwisata

2. Menampilkan foto dan video perjalanan wisata

3. Berbagi pengalaman melalui foto dengan maksud agar banyak orang melihat destinasi yang dikunjungi dan membuat destinasi menjadi lebih dikenal oleh banyak orang.

Namun demikian, ada dua orang mahasiswa pariwisata yang menyatakan kadang-kadang dan tidak tentu atau tidak sering menggunakan media sosial untuk menampilkan informasi perjalanan wisata yang dilakukannya.

Tingginya informasi yang disampaikan mahasiswa pariwisata mengenai penggunaan media sosial setelah berwisata, sejalan dengan hasil wawancara mengenai media sosial mempengaruhi mahasiswa untuk melakukan perjalanan wisata. Seluruh mahasiswa menyatakan bahwa informasi, foto dan video yang disampaikan melalui youtube, Instagram sangat mempengaruhi keiinginan mahasiswa melakukan perjalanan wisata yang diekspresikan dalam kalimat berikut:

1. ... " ya.. sangat kuat mempengaruhi untuk pergi ke suatu destinasi"

2. “... membuat saya tertarik mengunjungi destinasi wisata yang ditampilkan"

3. "iya.. biasanya saya berwisata setelah melihat suatu destinasi wisata dari medsos"

4. “... sosmed dapat bersifat advertising maupun persuasive pada penggunanya, sehingga dapat menimbulkan keiinginan pengguna untutk menggali informasi lebih banyak, begitupun dengan saya"

5. ".. terutama jika ada destinasi baru yang masih perawan, saya akan sangat senang bisa pergi kesana..."

Transkrip diatas menunjukkan bahwa mahasiswa pariwisata memiliki keiinginan untuk berkunjung ke destinasi setelah melihat foto, video dan mendapatkan informasi melalui media sosial.

Hal lain dalam penelitian ini adalah keiinginan mahasiswa mempromosikan destinasi melalui media sosial. Seluruh mahasiswa memberikan jawaban yang sama, bahwa mereka memiliki keiinginan untuk mempromosikan destinasi wisata melalui media sosial. Hal ini ditunjukkan dari hasil wawancara yang berisi:

1. "saya ingin mempromosikan kuliner daerah di destinasi tersebut"

2. "saya ingin atraksi wisata yang belum dikenal menjadi semakin dikenal dengan adanya promosi yang gencar dilakukan di sosmed"

3. "... ya saya ingin memperkenalkan keindahan Indonesia ke pranala luar"

4. “... keharusan saya membantu pemerintah memberi informasi kepada masyarakat luas mengenai suatu destinasi ... saya rasa media 
sosial merupakan pemasaran yang paling tepat pada era teknologi seperti sekarang ini"

5. “... medsos memberikan efek sangat besar dalam mempromosikan suatu destinasi... dengan saya mengupload dan memberikan review tentang destinasi wisata akan menimbulkan minat orang untuk berkunjung"

6. "saya ingin melakukan penjualan online melalui media sosial..."

Hasil yang sedikit berbeda, bahwa terdapat informasi yang disampaikan:

1. ".. belum yakin, belum ada benefit yang saya terima jika mempromosikan destinasi”.

2. "... punya keiinginan seperti mempromosikan destinasi, tapi sampai saat ini belum terlaksana".

\section{Perilaku online}

Perilaku online mahasiswa pariwisata memiliki karakteristik yang sama dengan kelompok Gen Y, yaitu memiliki kemudahan akses menggunakan teknologi, hal ini sejalan dengan studi yang dilakukan Kandell (1998). Perilaku ini juga ditunjukkan dengan lama waktu yang digunakan untuk media sosial, rata-rata sekitar 4-7 jam per hari. Banyaknya waktu yang digunakan untuk media sosial disebabkan juga oleh banyaknya akun media sosial yang dimiliki mahasiswa. Sehingga dapat disimpulkan, semakin banyak akun yang dimiliki, semakin banyak waktu yang diperlukan untuk mengelola akun media sosial tersebut.

Mahasiswa pariwisata aktif dalam menyebarkan informasi, foto dan video mengenai destinasi wisata yang dapat digunakan oleh konsumen lain. Hasil studi ini juga merupakan studi yang dilakukan oleh Brosdahl \& Carpenter (2011). Sebagai mahasiswa pariwisata, penelitian ini fokus pada konten pariwisata di media sosial. Konten pariwisata yang bisa diakses melalui media sosial menjadi koten penting yang selalu mendapat perhatian mahasiswa pariwisata. Hal ini ditunjukkan dengan seringnya mahasiswa pariwisata mencari informasi pada dua tahap perjalanan wisata, yaitu tahap pre-tour (sebelum melakukan kegiatan wisata) dan tahap post tour (setelah berwisata). Beragam informasi diperlukan oleh mahasiswa pariwisata, terutama yang berhubungan dengan destinasi, atraksi, harga, akses akomodasi, tren wisata terkini dan fasilitas lainnya yang diperlukan untuk berwisata. Semua informasi didapat melalui konten pada akun media sosial yang dimiliki mahasiswa pariwisata secara mudah.
Tahap post tour juga merupakan aktivitas yang banyak dilakukan mahasiswa pariwisata menggunakan media sosial. Hal ini digunakan untuk menuliskan, pengalaman yang pernah didapat mahasiswa pariwisata selama melakukan perjalanan wisata. Pada tahap post-tour ini, perilaku mahasiswa berkembang yang diungkapkan dengan perasaan bahagia dan menjadi penting atas respon positif yang banyak diberikan oleh orang yang melihat konten di akun media sosialnya. Kondisi ini sejalan dengan eMarketer (2011) yang menjelaskan bahwa usia mahasiswa menggunakan media sosial untuk berinteraksi dan berhubungan. Faktor penting lainnya yang muncul dari penelitian ini adalah mahasiswa pariwisata merasa senang dan merasa penting penting ketika mendapatkan umpan balik atas produk yang mereka gunakan.

\section{Kemampuan menggunakan media sosial}

Kemampuan mahasiswa pariwisata menggunakan media sosial ditunjukkan dengan kemampuan membuat blog dan vlog. Beragam konten pariwisata dibuat dengan cara mengabadikan destinasi melalui foto dan video, melakukan editing menggunakan aplikasi, membuat redaksi dalam konten, memberikan penilaian pada informasi, dan menyebarkan informasi dan pengalaman melalui media sosial. Hasil penelitian ini mengarah pada karakteristik mahasiswa pariwisata memiliki keiinginan untuk mengekspresikan diri mereka. Hasil penelitian ini sejalan dengan studi lain yang dilakukan Bradbury (2011) bahwa media sosial merupakan saluran media yang memberikan pengalaman berwisata. Studi ini memperkuat pernyataan bahwa mahasiswa pariwisata memiliki kemampuan menggunakan media sosial dalam beragam aktivitas yang berhubungan dengan kegiatan wisata.

Mayoritas mahasiswa pariwisata memiliki kemampuan menggunakan media sosial untuk membuat beragam konten, meskipun terbatas pada pemanfaatan aplikasi yang terdapat di media sosial saja. Kemampuan yang dimiliki cukup untuk menghasilkan beragam konten berupa blog, vlog atau artikel yang informatif dan menarik untuk dapat dilihat pada akun media sosialnya. Konten yang dihasilkan cukup menarik, karena mampu membuat orang yang melihat memberikan komentar pada informasi, foto atau video yang disampaikan.

\section{Potensi penggunaan media sosial}


Tujuan menggunakan media sosial adalah untuk berkomunikasi, yang diwujudkan dalam bentuk saling berinteraksi antara konsumen (Bradbury, 2011). Karena beragam konten bisa didapatkan melalui media sosial, maka Fotis (2012) juga menjelaskan bahwa media sosial menjadi salah satu media yang banyak digunakan untuk mencari informasi yang berhubungan dengan pariwisata. Studi ini juga memperkuat peryataan bahwa media sosial merupakan sumber informasi yang mampu mempengaruhi konsumen untuk melakukan perjalanan.

Dengan demikian, potensi penggunaan media sosial oleh mahasiswa pariwisata menekankan pada promosi destinasi wisata. Sesuai tujuan penelitian ketiga, maka media sosial merupakan media yang efektif untuk mempromosikan destinasi wisata. Beragam konten sebagai informasi mengenai destinasi wisata mampu dikembangkan oleh mahasiswa pariwisata.

Perkembangan fitur di media sosial memberikan peluang atau potensi lain dari penggunaan media sosial oleh mahasiswa pariwisata, seperti memunculkan keiinginan untuk melakukan bisnis di bidang pariwisata. Sejalan dengan penelitian Noti (2013) hasil studi ini menjelaskan bahwa media sosial merupakan media yang dapat digunakan untuk mendistribusikan dan memasarkan produk wisata kepada konsumen. Hal ini juga menjadi temuan penting dalam penelitian, mahasiswa pariwisata memiliki keiinginan untuk mempromosikan destinasi wisata melalui media sosial bahkan berbisnis di bidang pariwisata, seperti membuat dan menjual paket wisata, dan memberikan layanan jasa pemesanan kamar.

\section{SIMPULAN DAN REKOMENDASI}

Mahasiswa pariwisata memiliki karakteristik Gen $\mathrm{Y}$ yang secara khusus menghabiskan waktu cukup lama setiap harinya untuk menggunakan media sosial, karena jumlah akun media sosial yang dimiliki cukup banyak untuk dikelola. Kegiatan mahasiswa pariwisata menggunakan media sosial lebih banyak untuk menerima dan mengirim informasi. Mayoritas mahasiswa pariwisata memiliki kemampuan yang baik untuk membuat blog dan vlog dengan aplikasi yang tersedia di media sosial. Mahasiswa pariwisata memiliki keinginan untuk mempromosikan destinasi wisata melalui akun media sosial yang dimilikinya. Temuan penting lainnya adalah mahasiswa pariwisata menggunakan media sosial untuk melakukan bisnis di bidang pariwisata, seperti membuat dan menjual paket wisata, memberikan layanan jasa penjualan kamar hotel.

Hasil penelitian mengenai perilaku mahasiswa pariwisata menggunakan media sosial untuk mempromosikan destinasi wisata masih sangat terbatas. Mengingat destinasi wisata menjadi daya tarik penting bagi mahasiswa dan kelompok lainnya, maka penelitian lanjutan mengenai perilaku pengguna media sosial dalam mempromosikan destinasi wisata oleh kelompok mahasiswa lainnya perlu dilakukan. Keinginan mahasiswa pariwisata dalam memasarkan destinasi wisata melalui media social perlu dipantau bagaimana pada implementasi penggunaan media sosial dengan pendekatan konten pemasaran pada penelitan selanjutnya. Selain itu, perilaku menggunakan media sosial memberikan kontribusi terhadap promosi suatu destinasi wisata, maka penelitian mengenai dampak media sosial media terhadap pertumbuhan tingkat kunjungan atau pengetahuan terhadap suatu destinasi wisata perlu dipertimbangkan pada masa yang akan datang. Begitu juga dengan potensi lain dari perilaku pengguna media sosial oleh mahasiswa dan kelompok lainnya, terutama dalam membangun bisnis bidang pariwisata melalui media sosial perlu dikaji kembali untuk melihat perbedaan perilaku antar kelompok mahasiswa pariwisata.

\section{DAFTAR PUSTAKA}

Akehurst, G. (2009). User generated content: The use of blogs for tourism organisations and tourism consumers. Service Business, 3(1), 51-61.

Bennet, S., Maton, K., \& Kervin, L. (2008). The digital natives' debate: a critical review of the evidence. British Journal of educational Technology, 39(5), 775-786. doi: $\quad$ https://doi.org/10.1111/j.14678535.2007.00793.x

Bradbury, K. (2011). The Growing Role of Social Media in Tourism Marketing. Retrieved from http://kelseybradbury.weebly.com/upload s/1/0/9/2/10927387/tourismsocialmediacomm427.pdf

Brosdahl, D., \& Carpenter, J. (2011). Shopping orientations of US males: A generational cohort comparison. Journal of Retailing and Consumer Services, 18, 548-554. doi:https://doi.org/10.1016/j.jretconser.2 011.07 .005 
Charmaz, K. (2006). Constructing grounded theory: A practical guide through qualitative research. London: Thousand Oaks.

Digital Information World. (2017, February 8). Retrieved from digital information world.com:

https://www.digitalinformationworld.co $\mathrm{m} / 2017 / 02 /$ global-social-mediastatistics.html

eMarketer. (2011). Social media outlook for 2011. eMarketer Webinar, www.emarketer.com.

Fotis, J., Buchalis, D., \& Rossides, N. (2012). Social media use and impact during the holiday travel planning process, in information and communication technologies in tourism. Vienna: Springer - Verlag.

Furlow, N. (2011). Find us on Facebook: How cause marketing has embraced social media. Journal of Marketing development and competitiveness, 5(6), 61-64.

Hamzah, Y. (2013). Potensi media sosial sebagai sarana promosi interaktif bagi pariwisata Indonesia. Jurnal Kepariwisataan Indonesia, 8(3), 1-9.

Hanzaee, K., \& Aghasibeig, S. (2010). Iranian Generation Y Female Market Segmentation. Journal of Islamic marketing, 1(2), 165-176.

Kandell, J. (1998). Internet addiction on campus: the vulnerability of college students. Cyberpsychology \& behavior, 1(1).

Kaplan, A., \& Haenlein, M. (2010). Users of the world, unite! The challenges and oppportunities of Social Media. Business Horizon, 53(1), 59-68. doi:https://doi.org/10.1016/j.bushor.2009 .09 .003

Kemendag. (2015). Panduan optimalisasi media sosial untuk Kementerian Perdagangan RI. Jakarta: Pusat Hubungan Masyarakat Perdagangan.

Krisnamurthy, S., \& Dou, W. (2008). Advertising with User-Generated Content: A Framework and Research Agenda. Journal of Interactive Adverstising, 8(2), $1-4$.
Lange-Faria, W., \& Elliot, S. (2012). Understanding The Role of Social Media In Destination Marketing. Tourismos: An international multidisciplinary Journal of Tourism, 7(1), 193-211.

Mangold, W., \& Faulds, D. (2009). Social Media: The New Hybrid Element of The Promotion Mix. Business Horizons, 52(4), 357-365. doi:https://doi.org/10.1016/j.bushor.2009 .03 .002

Miles, B., \& Huberman, M. (1992). Analisis data kualitatif, buku sumber tentang metodemetode baru. Jakarta: UIP.

Mukaromah, K., Kusyanti, A., \& Perdanakusuma, A. R. (2018, April). Analisis Faktor-Faktor Yang Memengaruhi Pengguna SnapChat Membagikan Video Dengan Menggunakan Structural Equation Modeling. Jurnal Pengembangan Teknologi Informasi dan Ilmu Komputer, 2(4), 1582-1591. Retrieved from http://jptik.u.ac.id

Noti, E. (2013). Web 2.0 And The Its Iinfluence On The Tourism Sector. European Scientific Journal, 9(20). doi:http://dx.doi.org/10.19044/esj.2013.v $9 \mathrm{n} 20 \mathrm{p} \% 25 \mathrm{p}$

Palfrey, J., \& Gasser, U. (2008). Born digital: Understanding The First Generation of Digital Natives. New York: Basic Book.

Pantano, E., \& Di Pietro, L. (2013). From eTourism To f- Tourism: Emerging Issues From Negatif Tourists' Online Reviews. Journal of Hospotality and Tourism Technology, 4(3), 211-227. doi:https://doi.org/10.1108/JHTT-022013-0005

Smahel, D., Brown, B., \& Blinka, L. (2012). Association Between Online Frienship And Internet Addiction Among Adolescents And Emerging Adults. Developmental Psychology, 48(2), 381388.

Sugiyono. (2006). Metode penelitian kuantitaif kualitatif dan R\&D. Bandung: Alfabeta.

Syrett, M., \& Lammiman, J. (2003). Catch them if you can. Director, 57(3), 70-76. 
Werthner, H., \& Ricci, F. (2004). E-commerce And Tourism. Communcation of the $A C M, 47(12), 101-105$.

Wesner, M., \& Miller, T. (2008). Boomers and Millenials, Have Much In Common. Organizational Development, 26(3), 8996.

Zeng, B. (2013). Social media in tourism, Tourism and hospitality. Australia: The Northern Institute .

Zeng, B., \& Gerritsen, R. (2014). What Do We Know About Social Media In Tourism? A Review. Tourism Management Perspective, 10, 27-36. doi:https://doi.org/10.1016/j.tmp.2014.01 .001

Zeng, X., \& Gretzel, U. (2010). Role of social media in oline travel information search. Tourism Management, 31(2), 179-188. doi:https://doi.org/10.1016/j.tourman.200 9.02.016. 